\title{
Asialo-GM1 and asialo-GM2 are putative adhesion molecules for Moraxella catarrhalis
}

Received: 5 June 2001 / Published online: 27 March 2002

(C) Springer-Verlag 2002

\begin{abstract}
Moraxella catarrhalis is an important pathogen of respiratory and middle ear infections. We previously reported that the attachment of $M$. catarrhalis to pharyngeal epithelial cells is mediated by ganglioside M2 (GM2). Several sets of adhesins or receptors are involved in such attachment process. In this study, we used the same strains and similar bacterial culture conditions as those in our previous study, and demonstrated by thin layer chromatography that $M$. catarrhalis can also bind toasialo-GM1 $\left(\mathrm{Gg}_{4} \mathrm{Cer}\right)$ and asialo-GM2 $\left(\mathrm{Gg}_{3} \mathrm{Cer}\right)$. GalNAc $\beta 1 \rightarrow 4 \mathrm{Gal} \beta 1$ is a common sequence in both $\mathrm{Gg}_{4} \mathrm{Cer}$ and $\mathrm{Gg}_{3} \mathrm{Cer}$, and in many respiratory bacteria, this sequence acts as a receptor for attachment to host cells. Treatment of human pharyngeal epithelial cells with anti-GM2 and anti-Gg ${ }_{4} \mathrm{Cer}$ antibodies significantlydecreased attachment of $M$. catarrhalis to these cells; however, treatment with anti- $\mathrm{Gg}_{3} \mathrm{Cer}$ antibody did not decrease $M$. catarrhalis attachment. Immunofluorescence microscopy revealed that human pharyngeal epithelial cells are positive for $\mathrm{GM} 2$ and $\mathrm{Gg}_{4} \mathrm{Cer}$, but not for $\mathrm{Gg}_{3}$ Cer. Our results indicate that $\mathrm{Gg}_{4} \mathrm{Cer}$ on human pharyngeal epithelial cells, and $\mathrm{Gg}_{3} \mathrm{Cer}$,possibly on other cells, could serve as molecules for attachment of $M$. $c a$ tarrhalis.
\end{abstract}

Keywords Moraxella catarrhalis - Attachment · Gangliosides · Anti-ganglioside antibody

K. Ahmed $(\bowtie)$

Department of Molecular Biology and Genetics, Bilkent University, 06533 Ankara, Turkey

E-mail: ahmed@fen.bilkent.edu.tr

Fax: + 90-312-2665097

K. Ahmed · T. Nagatake

Department of Internal Medicine,

Institute of Tropical Medicine,

Nagasaki University, Nagasaki, Japan

Y. Suzuki · D. Miyamoto

Department of Biochemistry,

University of Shizuoka School of Pharmaceutical Sciences,

Shizuoka, Japan

\section{Introduction}

The pathogenicity of respiratory infection commences with the colonization of the pharyngeal epithelial cells after successful attachment of bacteria. Moraxella catarrhalis is an important organism associated with respiratory and middle ear infections, and attachment has been shown to be a pre requisite for pathogenicity of this bacterium [2]. The emergence of $\beta$-lactamase-producing M. catarrhalis [15] has made treatment of these infections with conventional $\beta$-lactam antibiotics difficult. Resistance in $M$. catarrhalis necessitates a search for new and effective treatment and prevention methods. Antibodies against adhesin and its receptor to block attachment have proved to be a promising approach to prevent infections [4]. Inhibition of glycosphingolipid (GSL) synthesis to deplete the GSLs of the target organism is another novel approach to prevent infections [17]. Therefore, it is essential to elucidate the adhesin and receptor involved in this attachment process.

Attachment of $M$. catarrhalis to human pharyngealepithelial cells is mediated by fimbriae [1] and the receptor for this bacterium on pharyngeal epithelial cells resides in the structure of ganglioside GM2 (GM2) [2]. The affinity of a single adhesin molecule for its receptor is considered to be relatively weak because an individual bacterium can have several adhesins that interact with multiple receptor molecules to produce firm binding [5]. Thus, it is possible that other receptors or adhesins are also involved in attachment of M. catarrhalis. Accumulating knowledge of the receptor specificity of bacterial adhesins can provide both an explanation of pathogenesis and the potential for developing inhibitors of bacterial attachment to prevent infections. The use of affinity thin layer chromatography (TLC) to screen carbohydrate-based receptors has revealed several features inherent to the receptor-adhesin interaction, including the recognition of internal receptor sequences, low affinity cooperative interactions, and receptorbinding variants of different tropism [23]. Therefore, in 


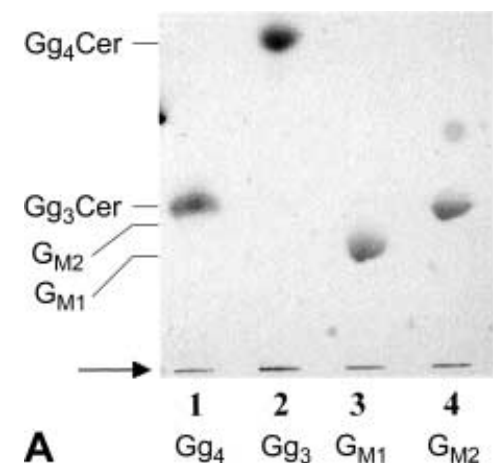

Fig. 1. Binding of Moraxella catarrhalis (strain B-88-152) to ganglioside.Left Plate (Silica gel 60, Merck, Darmstadt, Germany) sprayed withorcinol stain, after spotting asialo-GM1 $\left(\mathrm{Gg}_{4} \mathrm{Cer}\right)$, asialo-GM2 $\left(\mathrm{Gg}_{3} \mathrm{Cer}\right)$, ganglioside M1 (GM1) and ganglioside M2 (GM2) inlanes 1, 2, 3 and 4, respectively. Right Plate (Polygram,Sil $\mathrm{G}$, Machery-Nagel, Germany) showing reactivity of M.catarrhalis with $\mathrm{Gg}_{4} \mathrm{Cer}$ (lane 3) and $\mathrm{Gg}_{3} \mathrm{Cer}$ (lane 4), and no reactivity with GM1and GM2 (lanes 1 and 2) by immunostaining. There is a faint line in the GM1 lane, which is an artifact.The color of the band is the same as the background color and different fromthat of the immuno reactive bands. In lane 3 of the orcinol-stained TLC plate, there is only one band for GM1 and no band evidentat the level of $\mathrm{Gg}_{4} \mathrm{Cer}$ (lane 1). The arrow indicates the site ofthe spotted gangliosides. Both plates were developed inchloroform:methanol:12 mM $\mathrm{MgCl}_{2}$ (5:4:1, v/v/v). Gangliosideswere applied at $500 \mathrm{pmol} / \mathrm{lane}$

the present study we used TLC and a set of glycoconjugates to identify binding molecules for $M$. catarrhalis.

\section{Materials and methods}

\section{Bacteria}

Strains of $M$. catarrhalis, B-87-34, B-87-69, B-87-75, B-87-94, B-87133 , B-88-83, B-88-152 and Strain F (anon-fimbriated strain), isolated from the sputum of patients with respiratory infections, were used in this study. Strain B-88-152 was mainly used, unless otherwise stated. The bacteria were maintained in Mueller Hinton broth (Becton Dickinson Microbiology Systems, Cockeysville, Md.) containing $5 \%$ defibrinated horse blood, and stored at $-40^{\circ} \mathrm{C}$ until use.

\section{Generation of immune serum against M.catarrhalis}

Whole cell antibody against strain B-88-152 was generated by injecting a rabbit with live organisms, as described previously [1]. A dose of $1 \mathrm{ml}$ bacterial suspension in $1 \mathrm{ml}$ Freund's adjuvant (Difco Laboratories, Detroit, MI) was injected each ime in equally divided doses into two subcutaneous and two intramuscularsites. A total of four doses was administered at 2-week intervals. Two weeks after the last injection, blood was collected and the serum was stored at $-80^{\circ} \mathrm{C}$.

\section{Source of glycolipids}

The natural glycolipids used in this study were purified in our laboratory from the following sources: GM1a, GM1b, GD1a, GD1b,GT1b and GalCer, from bovine brain [9, 10, 26]; GlcCer, LacCer, $\mathrm{Gb}_{3} \mathrm{Cer}$ and $\mathrm{Gb}_{4} \mathrm{Cer}$, from porcine erythrocytes [3]; GM3 from human liver [21]; GM2, from Tay-Sachsbrain [25]; $\mathrm{Gg}_{4} \mathrm{Cer}$ and $\mathrm{Gg}_{3} \mathrm{Cer}$, from guinea pig erythrocytes $[20,30]$; and $\mathrm{IV}_{3} \mathrm{Neu} 5 \mathrm{Ac}-$ $\mathrm{nLc}_{4} \mathrm{Cer}$, from human red blood cells [13]. $\mathrm{nLc}_{4} \mathrm{Cer}$ was prepared from $\mathrm{IV}_{3} \mathrm{Neu} 5 \mathrm{Ac}-\mathrm{nLc} \mathrm{C}_{4} \mathrm{Cer}$ by sialidase treatment as described previously [19]. $\mathrm{Gg}_{4} \mathrm{Cer}$ was prepared by desialylation of GM1 with

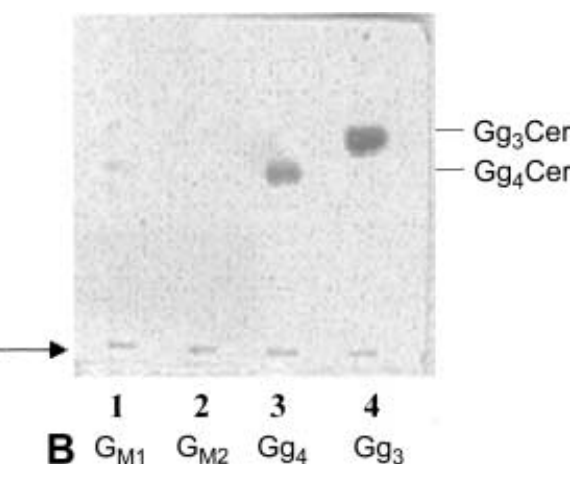

$1 \mathrm{M}$ formicacid at $80^{\circ} \mathrm{C}$ for $1 \mathrm{~h}$ [30], followed byQ-Sepharose column chromatography to remove acidic glycolipids [9]. The glycoconjugates finally isolated yielded a single spot on high performance silica gel (Polygram, Sil G, Macherey-Nagel, Germany). TLC was developed in two different solvent systems (neutral and basic),chloroform:methanol:12 $\mathrm{mM} \mathrm{MgCl}_{2}(5: 4: 1, \mathrm{v} / \mathrm{v} / \mathrm{v})$, and chloroform:methanol:2.5 $\mathrm{N}$ ammonia $(50: 40: 9, \mathrm{v} / \mathrm{v} / \mathrm{v})$, and then stained byorcinol- $\mathrm{H}_{2} \mathrm{SO}_{4}$ or resorcinol- $\mathrm{HCl}$, as described previously [29]. The structures of gangliosides GM1, GM2 and $\mathrm{Gg}_{3} \mathrm{Cer}$, were identified by nuclear magnetic resonance (NMR) and massspectrometry [10].

The following glycolipids, which were prepared from bovinebrain, were purchased from Sigma Chemical Co. (St. Louis, Mo.): $\mathrm{Gg}_{4} \mathrm{Cer}, \mathrm{GM} 1, \mathrm{Gg}_{3} \mathrm{Cer}$, GM2, GD1a, GD2, GT1b and GQ1b.

\section{TLC for attachment of $M$. catarrhalis with glycolipids}

TLC was performed with various glycolipids according to the methods described previously [28] with slight modification. Briefly, glycolipids were separated on a thin-layer plate (Polygram, Sil G, Macherey-Nagel) with a solvent system of chloroform:methanol:water (65:35:8, by volume). After chromatography of variousglycolipids and gangliosides, the plate was dried and then blocked with $1 \%$ bovine serum albumin (BSA; Sigma) in phosphate buffer solution (PBS) by shaking at room temperature for $2 \mathrm{~h}$. After five washes with PBS, the plate was incubated overnight at $4^{\circ} \mathrm{C}$ in $M$. catarrhalis suspension $\left(1 \times 10^{8} \mathrm{cfu} / \mathrm{ml}\right)$. After five washes with PBS, the plate was incubated for $2 \mathrm{~h}$ at $4^{\circ} \mathrm{C}$ with antibody against $M$. catarrhalis diluted in $0.1 \%$ BSA-PBS. After five washes with PBS, the plate was treated with horseradish peroxidase (HRP)conjugated protein $\mathrm{A}$ (Sigma) diluted with $0.1 \%$ BSA-PBS $(1: 1,000$ dilution) for $2 \mathrm{~h}$ at $4^{\circ} \mathrm{C}$. The plate was then washed five times with PBS and incubated with peroxidase substrate solution. The reaction was observed by examination with the naked eye.

\section{Generation of anti-ganglioside antibodies}

Polyclonal anti-GM2 and anti- $\mathrm{Gg}_{4} \mathrm{Cer}$ antibodies were prepared as described previously $[24,27]$. Briefly, each glycolipid was emulsified with a mixture of $2 \mathrm{ml}$ Freund's complete adjuvant and $3 \mathrm{mg}$ methylated BSA. The emulsion was injected into a rabbit intradermally four times every 2 weeks. Six weeks after the last injection, blood was collected and centrifuged to obtain the antiserum. The serum was incubated at $56^{\circ} \mathrm{C}$ for 30 min to inactivate complement. Each antibody was purified on an affinity column conjugated with the corresponding glycolipid antigen after adsorption of each antiserum with GM2 and $\mathrm{Gg}_{4} \mathrm{Cer}$, respectively, as described previously [8]. The purified antibodies were stored at $-80^{\circ} \mathrm{C}$ until use. Rabbit anti-Gg ${ }_{3} \mathrm{Cer}$ antibody was obtained commercially (Matreya Inc., Pleasant Gap, Pa.).

\section{Pharyngeal epithelial cells}

Pharyngeal epithelial cells were collected from a healthy adult male subject by scraping the oropharynx with a cotton swab. Cells from 
the swab were collected in $1 / 15 \mathrm{mM}$ PBS, $\mathrm{pH} 7.2$, and washed three times by centrifugation at $80 \mathrm{~g}$, each time for $10 \mathrm{~min}$ at room temperature. Finally, oropharyngeal cells were adjusted to a density of $2.5 \times 10^{4}$ cells $/ \mathrm{ml}$.

\section{Attachment assay}

For the adherence assay, cells were treated with different dilutions of anti-GM2, anti-Gg $\mathrm{Ger}_{4}$ and anti-Gg $\mathrm{Ger}_{3} \mathrm{Cerum}$ and normal rabbit serum (NRS) for 30 or $150 \mathrm{~min}$ at $37^{\circ} \mathrm{C}$. M. catarrhalis organisms, at a density of $1 \times 10^{8} \mathrm{cfu} / \mathrm{ml}$ were then mixed with cells andthe adherence assay was performed as described previously [2]

Fluorescence microscopy

Smears were prepared with a Cytospin (Shandon, Astmoor, England) using $0.5 \mathrm{ml}$ of cell suspension with a density of $2.5 \times 10^{4}$ cells $/ \mathrm{ml}$. To block nonspecific activity, each smear was incubated with $20 \mu \mathrm{l}$ of $10 \%$ goat serum at room temperature for $30 \mathrm{~min}$. Slides were subsequently incubated with $20 \mu \mathrm{l}$ anti-GM2, anti- $\mathrm{Gg}_{4} \mathrm{Cer}$ or anti-Gg $\mathrm{Ger}$ antibodies and placed in a moist chamber at $4^{\circ} \mathrm{C}$ overnight. The slides were rinsed three times with $0.01 \mathrm{M}$ PBS, after which they were treated with $20 \mu \mathrm{l}$ of secondary antibody (FITC-conjugated goat anti-rabbit IgM, Nordic Immunological Laboratories, Tilburg, The Netherlands) at a dilution of 1:5 and placed in a moist chamber in the dark for $3 \mathrm{~h}$. The slides were againrinsed with 0.01 M PBS to remove unbound antibody. As a negative control, the primary antibodies were substituted with normal rabbit serum or PBS. Slides were coverslipped and examined under a Nikon Microphot-FX microscope (Nikon Company, Tokyo, Japan). The staining intensity was assessed visually and graded semiquantitatively [18] into the following grades: $2+$, strong staining intensity; $1+$, weak staining intensity; -, absence of staining. The distribution of immunostaining was graded semiquantitatively as diffuse or focal. The grade of immunopositivity was assigned according to the dominant antigenic intensity and distribution observed in each specimen.

\section{Statistical analysis}

All data were expressed as mean \pm SD.Differences between groups were examined for statistical significance using the Student's $t$-test. A $P$ valueless than 0.05 denoted the presence of a statistically significant difference.

\section{Results}

Specificity of antiserum against ganglioside

Each anti-GM2 and anti-Gg ${ }_{4} \mathrm{Cer}$ antibody was highlyspecific for GM2 and $\mathrm{Gg}_{4} \mathrm{Cer}$, respectively, as assayed by an immunodiffusion test against each glycolipid [24], and TLC immunostaining method [27, 28]. Anti-GM2 antibody reacted with only GM2 in the Ouchterlony $(0.1 \mu \mathrm{mol})$ and TLC immunostaining $\operatorname{method}(1 \mathrm{nmol})$, but not with the structurally related brain gangliosides GM1,GM3, GD1a, GD1b, GT1b, or neutral glycolipids such as $\mathrm{Gg}_{4} \mathrm{Cer}$, glucosylceramide (GlcCer), galactosylceramide (GalCer), lactosylceramide (LacCer), ceramide trihexoside $(\mathrm{CTH})$ and globoside. Anti-Gg $\mathrm{Ge}_{4} \mathrm{Cer}$ antibody reacted with $\mathrm{Gg}_{4} \mathrm{Cer}$ but not with the above gangliosides or neutral glycolipids, such as GlcCer, GalCer, LacCer, $\mathrm{CTH}$ and globoside.

Binding specificity of $M$. catarrhalis with gangliosides on TLC plates

A positive reaction was obtained with $\mathrm{Gg}_{4} \mathrm{Cer}$ and $\mathrm{Gg}_{3} \mathrm{Cer}(.1)$, but no reactivity was observed with GalCer, GlcCer, LacCer, $\mathrm{Gb}_{3} \mathrm{Cer}, \mathrm{Gb}_{4} \mathrm{Cer}, \mathrm{nLc}_{4} \mathrm{Cer}, \mathrm{GM} 1 \mathrm{a}$, GM1b, GM2, GM3, GD1a, GD1b and GT1b (Table 1). Using commercially obtained gangliosides, all strains yielded positive reactions with $\mathrm{Gg}_{4} \mathrm{Cer}$ and $\mathrm{Gg}_{3} \mathrm{Cer}$ only, and no reaction was detected with GM1, GM2, GD1a, GD2, GT1b and GQ1b. Furthermore, no positive reaction was observed with GM2, even at $5 \mu \mathrm{g} /$ lane.

\section{Effects of antibodies on attachment of M.catarrhalis}

The number of bacteria attached to pharyngeal epithelial cells was not significantly different after treatment of cells with GM2 or $\mathrm{Gg}_{4} \mathrm{Cer}$ antibodies at 1:100 dilution
Table 1. Glycolipids used in thin layer chromatography and their reactivity with Moraxella catarrhalis

\begin{tabular}{|c|c|c|}
\hline Glycolipid & Structure & Reactivity \\
\hline GalCer & $\mathrm{Gal} \beta 1 \rightarrow \mathrm{Cer}$ & - \\
\hline GlcCer & $\mathrm{Glc} \beta 1 \rightarrow \mathrm{Cer}$ & - \\
\hline LacCer & $\mathrm{Gal} \beta 1 \rightarrow 4 \mathrm{Glc} \beta 1 \rightarrow \mathrm{Cer}$ & - \\
\hline $\mathrm{Gb}_{3} \mathrm{Cer}$ & $\mathrm{Gal} \alpha 1 \rightarrow 4 \mathrm{Gal} \beta 1 \rightarrow 4 \mathrm{Glc} \beta 1 \rightarrow \mathrm{Cer}$ & - \\
\hline $\mathrm{Gb}_{4} \mathrm{Cer}$ (globoside) & GalNAc $\beta 1 \rightarrow 3 \mathrm{Gal} \alpha 1 \rightarrow 4 \mathrm{Gal} \beta 1 \rightarrow 4 \mathrm{Glc} \beta 1 \rightarrow \mathrm{Cer}$ & - \\
\hline $\mathrm{nLc}_{4} \operatorname{Cer}$ (paragloboside) & $\mathrm{Gal} \beta 1 \rightarrow 4 \mathrm{GlcNAc} \beta 1 \rightarrow 3 \mathrm{Gal} \beta 1 \rightarrow 4 \mathrm{Glc} \beta 1 \rightarrow \mathrm{Cer}$ & - \\
\hline $\mathrm{Gg}_{4} \mathrm{Cer}($ asialo-GM1) & $\mathrm{Gal} \beta 1 \rightarrow 3 \mathrm{GalNAc} \beta 1 \rightarrow 4 \mathrm{Gal} \beta 1 \rightarrow 4 \mathrm{Glc} \beta 1 \rightarrow \mathrm{Cer}$ & + \\
\hline $\mathrm{Gg}_{3} \mathrm{Cer}$ (asialo-GM2) & GalNAc $\beta 1 \rightarrow 4 \mathrm{Gal} \beta 1 \rightarrow 4 \mathrm{Glc} \beta 1 \rightarrow \mathrm{Cer}$ & + \\
\hline GM1a & $\mathrm{Gal} \beta 1 \rightarrow 3 \mathrm{GalNAc} \beta 1 \rightarrow 4(\mathrm{Neu} 5 \mathrm{Ac} \alpha 2 \rightarrow 3) \mathrm{Gal} \beta 1 \rightarrow 4 \mathrm{Glc} \beta 1 \rightarrow \mathrm{Cer}$ & - \\
\hline GM1b & Neu $5 \mathrm{Ac} \alpha 2 \rightarrow 3 \mathrm{Gal} \beta 1 \rightarrow 3 \mathrm{GalNAc} \beta 1 \rightarrow 4 \mathrm{Gal} \beta 1 \rightarrow 4 \mathrm{Glc} \beta 1 \rightarrow$ Cer & - \\
\hline GM2 & GalNAc $\beta 1 \rightarrow 4(\mathrm{Neu} 5 \mathrm{Ac} \alpha 2 \rightarrow 3) \mathrm{Gal} \beta 1 \rightarrow 4 \mathrm{Glc} \beta 1 \rightarrow \mathrm{Cer}$ & - \\
\hline GM3 & Neu $5 \mathrm{Ac} \alpha 2 \rightarrow 3 \mathrm{Gal} \beta 1 \rightarrow 4 \mathrm{Glc} \beta 1 \rightarrow \mathrm{Cer}$ & - \\
\hline GD1a & $\begin{array}{l}\text { Neu5Ac } \alpha 2 \rightarrow 3 \mathrm{Gal} \beta 1 \rightarrow 3 \mathrm{GalNAc} \beta 1 \rightarrow 4(\mathrm{Neu} 5 \mathrm{Ac} \alpha 2 \rightarrow 3) \\
\quad \mathrm{Gal} \beta 1 \rightarrow 4 \mathrm{Glc} \beta 1 \rightarrow \mathrm{Cer}\end{array}$ & - \\
\hline GD1b & $\begin{array}{l}\mathrm{Gal} \beta 1 \rightarrow 3 \mathrm{GalNAc} \beta 1 \rightarrow 4(\mathrm{Neu} 5 \mathrm{Ac} \alpha 2 \rightarrow \mathrm{Neu} 5 \mathrm{Ac} \alpha 2 \rightarrow 3) \\
\mathrm{Gal} \beta 1 \rightarrow 4 \mathrm{Glc} \beta 1 \rightarrow \mathrm{Cer}\end{array}$ & - \\
\hline GT1b & $\begin{array}{l}\text { Neu5Ac } \alpha 2 \rightarrow 3 \mathrm{Gal} \beta 1 \rightarrow \mathrm{GalNAc} \beta 1 \rightarrow \\
\quad 4(\mathrm{Neu} 5 \mathrm{Ac} \alpha 2 \rightarrow 8 \mathrm{Neu} 5 \mathrm{Ac} \alpha 2 \rightarrow 3) \mathrm{Gal} \beta 1 \rightarrow 4 \mathrm{Glc} \beta 1 \rightarrow \mathrm{Cer}\end{array}$ & - \\
\hline
\end{tabular}


Table 2. Attachment of Moraxella catarrhalis, B-88-152, to pharyngeal cells treated with NRS, anti-GM2 or anti-asialo-GM1 (anti$\mathrm{Gg}_{4} \mathrm{Cer}$ ) antibodies. Data are mean $\pm \mathrm{SD}$, numbers in parentheses represent percentages (NRS normal rabbit serum, anti-GM2antiganglioside M2)

\begin{tabular}{llllll}
\hline Dilution & Incubation (min) & No. of experiments & NRS & Anti-GM2 & Anti-Gg Cer \\
\hline $1: 100$ & 30 & 4 & $26 \pm 11.2(100)$ & $22.8 \pm 5.8(87.7)$ & $29.9 \pm 14.7(115.0)$ \\
$1: 50$ & 30 & 5 & $31 \pm 9.7(100)$ & $11.6 \pm 3.2^{\mathrm{a}}(37.4)$ & $26.2 \pm 3.8(84.5)$ \\
$1: 100$ & 150 & 5 & $9.7 \pm 2.2(100)$ & $3.7 \pm 1.4^{\mathrm{b}}(38.1)$ & $3.7 \pm 0.7(38.1)$ \\
\hline
\end{tabular}

${ }^{a} P<0.01$ between NRS and anti-GM2, $\mathrm{P}<0.001$ between anti-Gg $\mathrm{Ger}_{4}$ and anti-GM2

${ }^{\mathrm{b}} \mathrm{P}<0.005$ between NRS and anti-GM2, $\mathrm{P}<0.005$ between NRS and anti-Gg $\mathrm{Gg}_{4} \mathrm{Cer}$

(Table 2 ), compared with NRS treatment. However, treatment of cells with GM2 antibody at 1:50 dilution significantly decreased the number of adherent bacteria, compared with cells treated with $\mathrm{Gg}_{4} \mathrm{Cer}$ antibody $(P<0.001)$ and NRS $(P<0.01)$. There was no difference in attachment between $\mathrm{Gg}_{4}$ Cer antibody-treated and NRS-treated cells. Extension of the incubation time for pharyngeal epithelial cells and antibodies (1:100 dilution) to $2.5 \mathrm{hr}$ esulted in a significant decrease in attachment, to both $\mathrm{Gg}_{4}$ Cer-and GM2-treated cells $(P<0.005)$ compared with NRS-treated cells (Table 2$).$ However, when cells were treated with anti- $\mathrm{Gg}_{3} \mathrm{Cer}$ (1:100 dilution) antibody for $2.5 \mathrm{~h}$, there was no significant decrease in attachment of bacteria to anti- $\mathrm{Gg}_{3} \mathrm{Cer}-$ treated cells $(9.9 \pm 8.3$ bacteria/cell), compared with the control (14.7 \pm 11.5 bacteria/cell).

\section{Immuno fluorescence microscopy}

In the smears of anti-GM2- and anti-Gg $g_{4}$ Cer-treated cells, more than $5-10 \%$ and less than $5 \%$ of the cells were positively immunostained, respectively. The staining intensity of positive cells in both smears was of $1+$ intensity. Immunostaining of GM2 was evident as diffuse and granular staining, while weak and sparse staining for $\mathrm{Gg}_{4} \mathrm{Cer}$ was noted in epithelial cells (Fig. 2). When primary antibodies were replaced by NRS and PBS, no specific staining was noted. No difference was observed among smears immunostained with anti$\mathrm{Gg}_{3} \mathrm{Cer}$ antibody, NRS and PBS.

\section{Discussion}

The host cell receptors for several bacteria are glycosphingolipid in nature $[11,14,22,31]$. In the attachment process, several sets of adhesin receptor interactions exist for establishment of strong attachment [7]. In the present study using TLC, we found that $M$. catarrhalis could only bind with $\mathrm{Gg}_{4} \mathrm{Cer}$ and $\mathrm{Gg}_{3} \mathrm{Cer}$. GalNAc $\beta 1 \rightarrow 4 \mathrm{Gal} \beta 1$ is a common sequence for both $\mathrm{Gg}_{4} \mathrm{Cer}$ and $\mathrm{Gg}_{3} \mathrm{Cer}$, and for several respiratory bacteria, this sequence may act as an internal sequence for attachment [15]. However, in a previous study using an attachment inhibition assay with commercially available gangliosides, we demonstrated that the receptor for $M$. catarrhalis liesin the sequence of GM2 [2]. In that study, $\mathrm{Gg}_{4} \mathrm{Cer}$ could not inhibit attach- ment even when used at higher concentrations [2]. The receptor-binding specificity of bacteria has been reported to be different depending on the microbes' environment, for example, growth on agar plates or in liquid culture [16]. However, in both of our studies, the same strains of $M$. catarrhalis were used under the same bacterial culture conditions. Moreover, to rule out any differences between commercially obtained and in-house gangliosides, the binding of $M$. catarrhalis to gangliosides from both sources was compared in this study. Interestingly, it was evident with gangliosides from both sources that
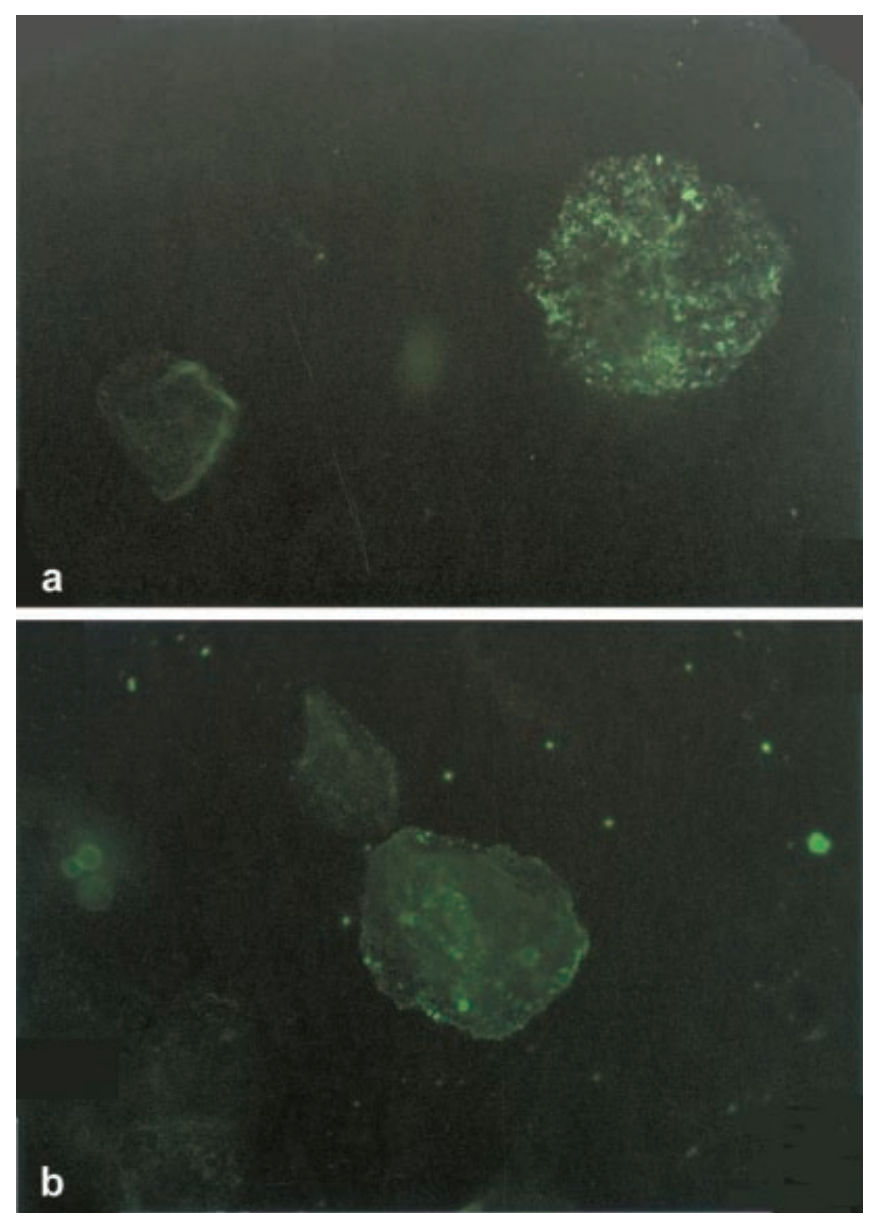

Fig. 2. Immunostaining of ganglioside GM2 (a) showing diffuse granular staining on pharyngeal epithelial cells. In contrast to ganglioside GM2 staining, weak and sparse staining for $\mathrm{Gg}_{4} \mathrm{Cer}$ (b) is noted on pharyngeal epithelial cells 
M. catarrhalis can bind with only $\mathrm{Gg}_{4} \mathrm{Cer}$ and $\mathrm{Gg}_{3} \mathrm{Cer}$, and even larger amounts of GM2 ganglioside did not show any reactivity. This difference between TLC and attachment inhibition assays was also observed in receptor identification of Escherichia coli, where class II adhesin binds equally well to globoside and to Forssman glycolipid or globo A glycolipid when they are presented on thin layer chromatograms. However, on intact cells only globoside is recognized [12]. Conversely, Burkholderia pseudomallei exhibited attachment to the $\mathrm{Gg}_{4} \mathrm{Cer}-\mathrm{Gg}_{3} \mathrm{Cer}$ receptor complex in both TLC and attachment inhibition assay [6].

Logically, the presentation that the bacteria select for optimum colonization should be membrane-dependent presentation of target cells, and the membrane location produces a higher selectivity in binding to glycolipids than when these appear on TLC [12]. In TLC, there is multivalent presentation of the receptor, enabling detection of low-affinity, cooperative multi-site interactions that would escape detection by soluble univalent receptors in attachment inhibition experiments [23]. We propose that multivalent presentation of $\mathrm{Gg}_{4} \mathrm{Cer}-$ $\mathrm{Gg}_{3} \mathrm{Cer}$ can act as a binding site for $M$. catarrhalis. It is possible that weak binding between $M$. catarrhalis and GM2 occurred on the TLC plate and that the interaction was disturbed by the many washes that are required for the TLC assay [31]. The human pharyngeal cell surface is more complex than the TLC plate; there are many macromolecules present that may enhance or prevent access of bacteria to bind with a particular receptor. Fluorescence microscopy revealed that GM2 and $\mathrm{Gg}_{4} \mathrm{Cer}$ were both present on the human pharyngeal epithelial cells and there was a significant decrease of attachment after cells were treated with anti-GM2 and anti- $\mathrm{Gg}_{4} \mathrm{Cer}$ antibodies, indicating that these molecules may act as receptors for $M$. catarrhalis on human pharyngeal epithelial cells. However, prolonged incubation of cells with $\mathrm{Gg}_{4}$ Cer antibody was necessary to achieve significant attachment inhibition, indicating that access of antibody to the $\mathrm{Gg}_{4} \mathrm{Cer}$ on the cell surface is not easy. The lack of a statistically significant decrease in attachment of $M$. catarrhalis to cells treated with anti$\mathrm{Gg}_{3}$ Cerantibodies may reflect the unavailability of $\mathrm{Gg}_{3} \mathrm{Cer}$ on pharyngeal epithelial cells, as shown by immunofluorescence microscopy. It is possible that $\mathrm{Gg}_{4} \mathrm{Cer}-\mathrm{Gg}_{3} \mathrm{Cer}$ may be shielded by neighboring molecules in the membrane. Further investigations are required to confirm this observation.

A working model predicts that two or multi-step mechanisms are involved in the attachment process. In the first step, a receptor mediates the target ingand tropism of the bacteria, and in the second step, a receptor establishes a true cell membrane attachment or mediates the penetration into cells. To maintain selectivity, the second step receptors cannot be directly accessible from outside of the cells [12]. Further studies are needed to determine the exact receptors required for the first stage of attachment and the next stage of firm binding of $M$. catarrhalis.
Acknowledgements We thank Prof. Norman Radin for critically reviewing this manuscript. We are indebted to Drs. Mohammad S.Razzaque, Arifa Nazneen and Lyndon K. Mwape for their extensive cooperation. This study was supported in part by a grant from the Japan-US Cooperative Medical Sciences Program on Acute Respiratory Infections and an International Cooperation Grant from the Ministry of Health and Welfare, Japanese Government (grant no. 8 ko 3).

\section{References}

1. Ahmed K (1992) Fimbriae of Branhamella catarrhalis as possible mediators of adherence to pharyngeal epithelial cells. Acta Pathol Microbiol Immunol Scand 100:1066-1072

2. Ahmed K, Matsumoto K, Rikitomi N, Nagatake T (1996) Attachment of Moraxella catarrhalis to pharyngeal epithelial cells is mediated by a glycosphingolipid receptor. FEMS Microbiol Lett 135:305-309

3. Clarke JT, Wolfe LS, Perlin AS (1971) Evidence for a terminal-D-galactopyranosyl residue in galactosylgalactosylglucosyl ceramide from human kidney. J Biol Chem 246:5563-5569

4. Connell H, Hedlund M, Agace W, Svanborg C (1997) Bacterial attachmentto uroepithelial cells: mechanisms and consequences. Adv Dent Res:11:50-58

5. Gibbons RJ, Hay DI, Childs III WC, Davis G (1990) Role of cryptic receptors (cryptitopes) in bacterial adhesion to oral surfaces. Arch Oral Biol 35 [Suppl]:107S-114S

6. Gori AH, Ahmed K, Martinez G, Masaki H, Watanabe K, Nagatake T (1999) Mediation of attachment of Burkholderia pseudomallei to human pharyngeal epithelial cells by asialoganglioside GM1-GM2 receptor complex. Am J Trop Med Hyg 61:473-475

7. Hasty DL, Ofek I, Courtney HS, Doyle RJ (1992) Multiple adhesins of Streptococci. Infect Immun 60:2147-2152

8. Hirabayashi Y, Suzuki T, Suzuki Y, Taki T, Matsumoto M, Higashi H, Kato S (1983) A new method for purification of anti-glycosphingolipid antibody. Avian anti-hematoside (NeuGc) antibody. J Biochem 94:327-330

9. Hirabayashi $\mathrm{Y}$, Nakao T, Matsumoto M, Obata K, Ando S (1988) Improved method for large scale purification of brain ganglioside by Q-sepharose column chromatography: immunochemical detection of c-series polysialogangliosides in adult bovine brains. J Chromatogr 445:377-384

10. Hirabayashi Y, Hyogo A, Nakao T, Tsuchiya K, Suzuki Y, Matsumoto M, Kon K, Ando S (1990) Isolation and characterization of extremely minorgangliosides, GM1b and GD1a in adult bovine brains as developmentally regulated antigens. $\mathrm{J}$ Biol Chem 265:8144-8151

11. Karlsson K-A (1989) Animal glycosphingolipid as membrane attachment sites for bacteria. Annu Rev Biochem 58:309-350

12. Karlsson K-A, Angstrom J, Bergstrom J, Lanne B (1992) Microbial interaction with animal cell surface carbohydrates. Acta Pathol Microbiol Immunol Scand 100 [Suppl 27]:71-83

13. Koscielak J, Plasek A, Gorniak H, Gardas A, Gregor A (1973) Structures of fucose0-containing glycolipids with $\mathrm{H}$ and $\mathrm{B}$ blood group activity and of sialic acid and glucosamine containing glycolipid of human erythrocyte membrane. Eur J Biochem. 37:214-225

14. Krivian HC, Ginsburg V, Roberts DD (1988) Pseudomonas aeruginosa and Pseudomonas cepacia isolated from cystic fibrosis patient bind specifically to gangliotetraosylceramide (Asialo GM1) and gangliotriaosylceramide (Asialo GM2). Arch Biochem Biophys260:493-496

15. Martinez G, Ahmed K, Watanabe K, Tao M, Nagatake T (1998) Changes in antimicrobial susceptibility to Moraxella catarrhalisover a ten year period. J Infect Chemother 4:139-141

16. Miller-Podraza $\mathrm{H}$, Milh MB, Teneberg S, Karsson K-A (1997). Binding of Helicobacter pylori to sialic acid-containing glycolipids of various origins separated on thin-layer chromatograms. Infect Immun 65:2480-2482 
17. Radin NS (1999) Chemotherapy by slowing glucosphingolipid synthesis. Biochem Pharmacol 57:589-595

18. Razzaque MS, Nazneen A, Taguchi T (1998) Immunolocalization of collagen and collagen binding heat shock protein 47 in fibrotic lung diseases. Mod Pathol 11:1183-1188

19. Saito M, Sugano K, Nagai Y (1979) Action of Arthrobacter ureafaciens sialidase on sialoglycolipid substrates. Mode of action and highly specific recognition of the oligosaccharide moiety of ganglioside GM1. J Biol Chem 254:7845-7854

20. Seyama Y, Yamakawa T (1974) Chemical structure of glycolipid of guinea-pig red blood cell membrane. Chemical structure of glycolipid of guinea-pig red blood cell membrane. J Biochem 75:837-842

21. Seyfried TN, Ando S, Yu RK (1978) Isolation and characterization of human liver hematoside. J Lipid Res 19:538-543

22. Siaman L, Prince A (1993) Pseudomonas aeruginosapili bind to asialo GM1 which is increased on the surface of cystic fibrosis epithelial cells. J Clin Invest 92:1875-1880

23. Stromberg N (1990) Carbohydrates as recognition molecules for bacterial adhesins: methodology and characteristics. Arch Oral Biol 35 [Suppl]:131S-135S

24. Suzuki Y, Morioka T, Matsumoto M (1980) Action of orthoand paramyxovirus neuraminidase on gangliosides hydrolysis of ganglioside GM1 by Sendai virus neuraminidase. Biochim Biophys Acta 619:632-639

25. Suzuki Y, Matsunaga M, Matsumoto M (1985) N-Acetylneuraminyl-lactosylceramide, GM3-NeuAc, a new influenza A virus receptor which mediates the adsorption-fusion process of viral infection: binding specificity of influenza A/Aichi/2/ $68(\mathrm{H} 3 \mathrm{~N} 2)$ to membrane associated GM3 with different molecular species of sialic acid. J Biol Chem 260:1362-1365
26. Suzuki $Y$, Nagao $Y$, Kato $H$, Matsumoto M, Nerome $K$, Nakajima K, Nobusawa E (1986) Human influenza A virus hemagglutinin distinguishes sialyloligosaccharides in membrane associated gangliosides as its receptor which mediate the adsorption and fusion process of virus infection. Specificity for oligosaccharide and sialic acids and the sequence to which sialic acid is attached. J Biol Chem 261:17057-17061

27. Suzuki Y, Hidari K, Matsumoto M, Ikeda M, Tsuchida N (1989) Altered ganglioside expression in ras-oncogene-transformed cells. J Biochem 106:34-37

28. Suzuki Y, Nishi H, Hidari K, Hirabayashi Y, Matsumoto M, Kobayashi T, Watari S, Yasuda T, Nakayama J, Maeda $\mathrm{H}$, Katsutama T, Kanai M, Kiso M, Hasegawa A (1991) A new monoclonal antibody directed to sialyl alpha $2 \rightarrow 3$ lactoneotetraosylceramide and its application for detection of humangastrointestinal neoplasms. J Biochem 109:354-360

29. Suzuki Y, Nakao T, Ito T, Tada Y, Xu G, Suzuki T, Kobayashi Y, Kimura Y, Yamada A, Sugawara K, Nishimura H, Kitami F, Makamura K, Deya E, Kiso M, Hasegawa A (1992) Structural determination of gangliosides that bind to influenza $\mathrm{A}, \mathrm{B}$, and $\mathrm{C}$ viruses by an improved binding assay: strain specificreceptor epitopes in sialo-sugar chains. Virology 189:121-131

30. Svennerholm L, Mannson JE, Li YT (1973) Isolation and structural determination of a novel ganglioside, a disialosylpentahexosylceramide from human brain. J Biol Chem 248:740-742

31. Alphen L van, Geelen-van den Broek L, Blass L, Ham M van, Dankert J (1991) Blocking of fimbriae mediated adherence of Hemophilus influenzae by sialyl gangliosides. Infect Immun 59:4473-4477 